\title{
Transoral Incisionless Fundoplication TIF 2.0 with "EsophyX Z"»" Device for GERD: Seven Years after Endo Lumenal Fundoplication. World's First Case Report
}

\author{
Alexandru Eugen Nicolau ${ }^{\text {, Adrian Lobonțiu² }}$ \\ 1Department of Surgery, Emergency Clinical Hospital Bucharest, Romania \\ 2EndoGastric Solutions, Redmond, WA, USA
}

Corresponding author:

Alexandru Eugen Nicolau, MD, PhD Department of Surgery Emergency Clinical Hospital Bucharest, Romania

E-mail: aenicolau@gmail.com

Abbreviations:

TIF - Transoral Incisionless

Fundoplication;

GERD - Gastroesophageal Reflux Disease;

ELF - Endo Lumenal Fundoplication; EGD - Esophagogastroduodenoscopy; HH - Hiatal Hernia;

LES - Lower Esophageal Sphincter; PPl's - Proton Pump Inhibitors; LNF - Laparoscopic Nissen Fundoplication;
Received: 25.09.2018 Accepted: 06.11 .2018

\section{Rezumat}

Reoperatie folosind fundoplicatura endoscopică cu "EsophyX $Z^{\otimes \prime " ~}$ pentru BRGE recidivată după fundoplicatura endoscopică cu “EsophyX $2^{\otimes ⿰}$ în premieră mondială. Prezentare de caz

Fundoplicatura endoscopică cu dispozitivul EsophyX (FEE) la pacienții cu BRGE riguros selectați, este eficace, sigură şi durabilă. Prezentăm cazul unui pacient de 63 de ani (unul dintre autori) cu simptomatologie de BRGE cu debut în urmă cu 15 ani cu simptome tipice şi atipice. In 2009, EDS evidențiază o hernie hiatală (HH) de $3 \mathrm{~cm}$ şi o esofagită erozivă Los Angeles B. S-a efectuat o FEE cu dispozitivul EsophyX $2 \circledR$ (EndoGastric Solutions, Inc., Redmond, WA, USA). Postoperator simptomele au dispărut, la EDS esofagita era vindecată. La 6 ani postoperator, simptome atipice de BRGE au reapărut (răguşeală), la EDS s-a evidențiat o $\mathrm{HH}$ de $2 \mathrm{~cm}$, esofagită erozivă Los Angeles A, pH-metria cu impedață confirmă refluxul, scor DeMeester 44,5. In 2016 (7 ani de la FEE) se efectuează o nouă FEE, de asta cu noul dispozitiv perfecționat, EsophyX Z®. Acest dispozitiv se acționează ca un "stapler", este mai uşor de manevrat şi mai sigur. Durata FEE cu noul dispozitiv a fost la jumătate comparativ cu vechiul dispozitiv. Simptomele atipice au dispărut, EDS efectuată la 90 de zile postoperator de aspect normal, pH-metria cu impedanță efectuată la 13 luni postoperator scorul DeMeester era de 8, în limite normale. Este prima reoperație mondiala cu noul dispozitiv EsophyX $Z^{\circledR}$ după FEE cu rezultate postoperatorii bune şi cu reducerea considerabilă a duratei intervenției. 
Cuvinte cheie: BRGE recidivată, EsophyX Z, fundoplicatura endoscopică, reoperație, premieră mondială

\begin{abstract}
Transoral Incisionless Fundoplication (TIF) with EsophyX device for a well selected GERD patient population has proven its efficacy, safety and durability. We present a case report of a male, $63 \mathrm{y} \mathrm{old}$, with typical and atypical GERD symptoms started 15 years ago. The esophagogastroduodenoscopy (EGD) showed a Hiatal Hernia (HH) of $3 \mathrm{~cm}$ and an erosive esophagitis Los Angeles Grade B. The first surgery was performed 7 years ago, in March 2009: a TIF with the EsophyX $2^{\circledR}$ device (EndoGastric Solution, Inc., Redmond, WA, United States). Post-surgery the symptoms were controlled, completely eliminated, the EGD showing the healing of the esophagitis. Six years after the surgery the sore throat re-appears, while the EGD shows a $2 \mathrm{~cm}$ hiatal hernia and erosive esophagitis Los Angeles Grade A. The Impedance $\mathrm{pH}$-metry confirms GERD with a DeMeester score of 44.5. In 2016 (7 years after first procedure) a second and new TIF 2.0 procedure, this time with EsophyX Z device is performed. The EsophyX Z device is an automatic stapler-like fastener delivery system, easier of use, faster, safer and more reproducible (standardized fastener delivery). The time of the procedure was significantly reduced, compared to first procedure. The patient is now symptom free, EGD is normal, the impendance ph metry at 13 months post-surgery showed a normal DeMeester score at 8. This is a World's first case report of a TIF 2.0 procedure with EsophyX Z device 7 years after a first TIF procedure with EsophyX 2 device, with excellent results and a significant reduction of the time for the procedure.
\end{abstract}

Key words: recurrent GERD, EsophyX Z, redo transoral incisionless fundoplication (TIF 2.0), first worlide case report

\section{Introduction}

The Gastroesophageal Reflux Disease (GERD) represents one of the most frequent benign upper gastro intestinal condition in developed countries. It continues to increase its incidence, significantly affecting patients' quality of life being also a risk factor for Barrett's esophagus (1).

It is caused by altering the anti-reflux barrier mechanisms, in particular the lower esophageal sphincter (LES) function and competence (2). The initial approach of treatment consists in lifestyle changes, with or without PPI's (Proton Pump Inhibitors), although 30 to $40 \%$ of patients are refractory to optimized PPI medication (3). PPI refractory patients, patients with severe symptoms, with atypical symptoms, regurgitation, large hiatal hernias are surgical candidates, the gold standard surgical treatment being the LNF (Laparoscopic Nissen Fundoplication), with good results at long term follow up, at expense of post fundoplication syndromes (gas bloat, dysphagia, inability to vomit and belch), in particular when performed by low volume experienced surgeons $(2,3,4)$.

Only $0.5 \%$ of GERD patients receive surgical treatment in the US, those $30-40 \%$ refractory to PPI's patients or those patients who decline surgery because of the new onset symptoms post fundoplication, represent the "treatment gap" patients $(5,6)$. For well selected patient population, in the last few years, new options of minimally invasive surgical (endoscopic or laparoscopic) options are available. These new techniques are indicated for this well selected subgroup of patients, improving the LES function, without modifying the anatomy, being more efficient compared to PPI's, with less side 
effects compared to LNF and technically easier to be performed $(7,8)$. All endoscopic, endoluminal techniques improve and augment the LES function, either by thermal therapy (radiofrequency) or by mimicking the antireflux long term well proven fundoplications. The new laparoscopic techniques, augment the LES by implanting a magnetic ring around the distal esophagus, or a foreign body comparable to a pacemaker, with two electrodes placed at the LES, stimulating its function (8).

Transoral Incisionless Fundoplication or TIF 2.0 with EsophyX device (Endogastric Solutions, Redmond, WA, USA) TIF 2.0 is the most known and used endoluminal technique, with more than 22,000 procedure worldwide, performing a gastroesophageal valve, recreating the angle of Hiss, reproducing the well known principles of Nissen Fundoplication (2). TIF 2.0 is performed by a single use device, being now automatic, stapler-like device, at its third iteration: EsophyX Z (Fig. 1) (9).

We present a case report of a patient who received in 2009 the ELF (EndoLuminal Fundoplication), with the EsophyX2 device, which is not commercialized anymore. The patient presents with new GERD symptoms for which he received 7 years later, in 2016 the TIF 2.0 procedure with the new automatic last iteration of the EsophyX Z device, being the first Worldwide patient receiving this new last generation of procedure (TIF 2.0) with the last iteration of the device (EsophyX Z).

\section{Case Report}

The patient A.E.N., 63 year old male, has atypical symptoms of GERD since 2015, with matinal dysphonia, and chronic laryngitis. The patient presented typical GERD symptoms, since 2001. In the beginning, the patient's history describes pyrosis, and acid regurgitations with postprandial and sporadic manifestations, triggered by alcohol intake (white wine) a/o coffee. The tobacco consumption was resumed in 2004, with progressive weight gain, culminating with an excess weight of $10 \mathrm{~kg}$ and a BMI of 33. The patient did not take any PPI's , but only occasional H2 receptors (Famotidine

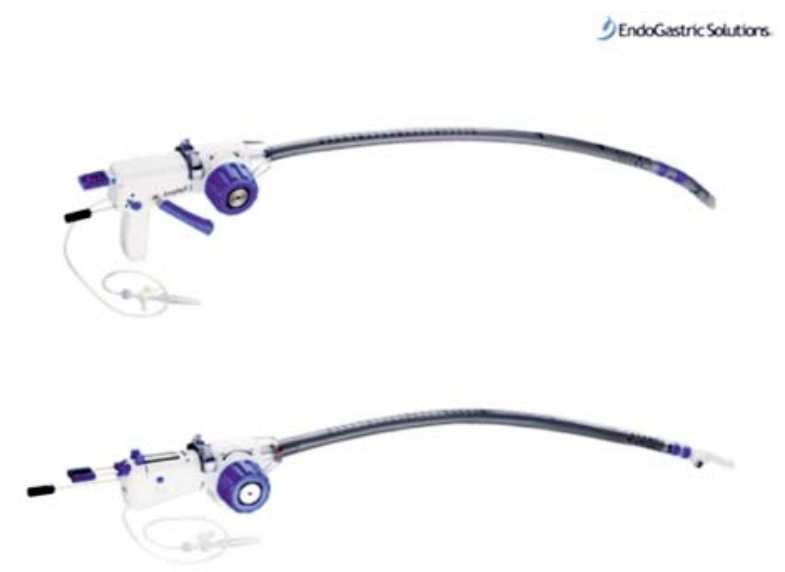

Figure 1. EsophyX Z® and EsophyX $®$ (Reprint permission EndoGastric Solution)

$20 \mathrm{mg}$ ). In 2007, typical symptoms started to manifest on a daily basis. No PPI treatment was administered at this time neither. The patient re-starts the physical activity (road cycling), improving his BMI at 31.1 in 2009. Atypical symptoms appear in 2009: matinal dysphonia, and chronic laryngitis. In 2008 the patient attends a TIF workshop at EITS in Strasbourg, France where he learns about the new endoluminal therapy the endoscopic partial fundoplication with EsophyX device (FEE). In February 2009 an ENT examination confirms the diagnosis of LPR (Laringo Pharyngeal Reflux), while the EGD confirms a Hiatal hernia of $3 \mathrm{~cm}$ with Los Angeles grade B Esophagitis (Fig. 2).

In March 2009 the patient receives the ELF procedure with EsophyX 2 by one of the authors (A.L.) during a surgery symposium and demonstration treating live 4 patients (10). The patient is under general anesthesia with nasotracheal intubation. The procedure takes 43 minutes with a total of 30 fasteners deployed (Fig. 3). The patient is discharged 6 hours postoperatory getting back on routine activity 72 hours later. The diet for 4 weeks consisted of liquids (10 days), and soft food (20 days). The EGD post procedure was performed at 3 months, showing a normal physiological constructed gastro-esophageal valve. Two additional EGD's in 2011 and 2013 showed normal aspect of the GEJ. Lifestyle changes and constant physical activity improved the BMI to 

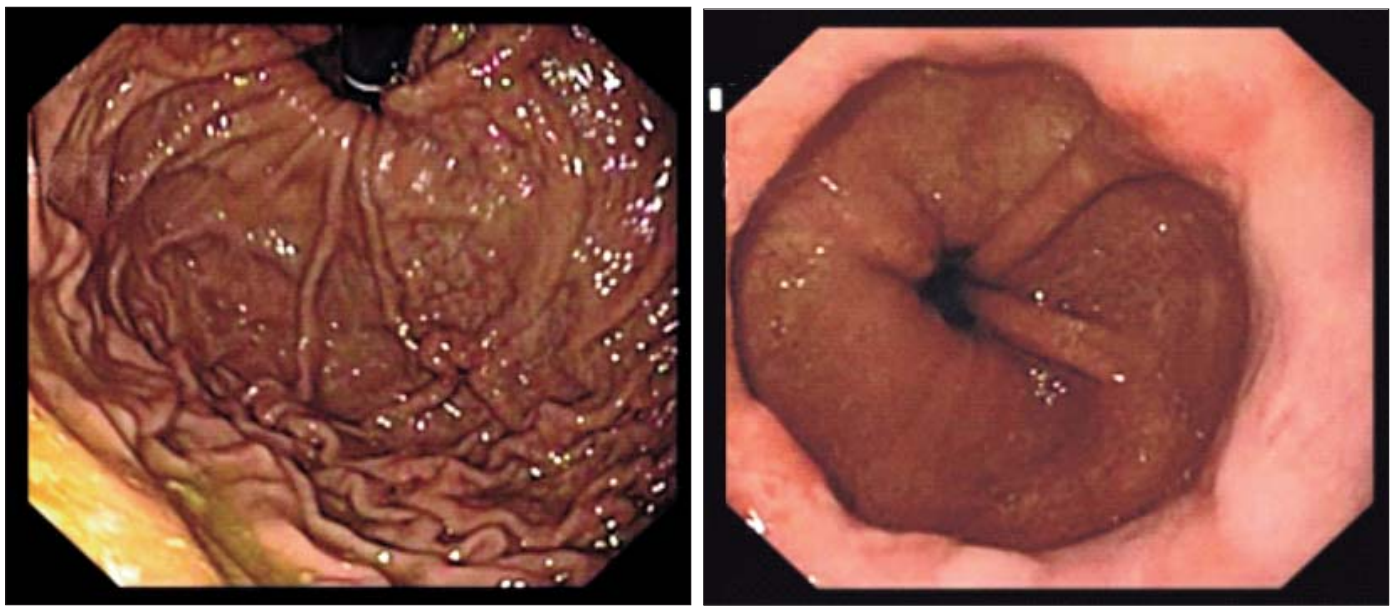

Figure 2. EGD February 2009

27. The patient is asymptomatic until 2015, when atypical symptoms re-occur. The PPI treatment only partially improves the symptoms. The EGD performed in February 2016 shows a $2 \mathrm{~cm}$ hiatal hernia, Los Angeles grade A esophagitis, with 2 visible fasteners (Fig. 4). The $\mathrm{pH}$ impedance test confirms the acid reflux with total acid exposure percentage time $12 \%$ and a DeMeester score of 44.2 (Fig. 5).

In June 2016 the patient receives a TIF 2.0 procedure with EsophyX Z device, performed by the same surgeon (A.L.). The TIF 2.0 is performed under general anesthesia with orotracheal intubation, 22 minutes procedure with

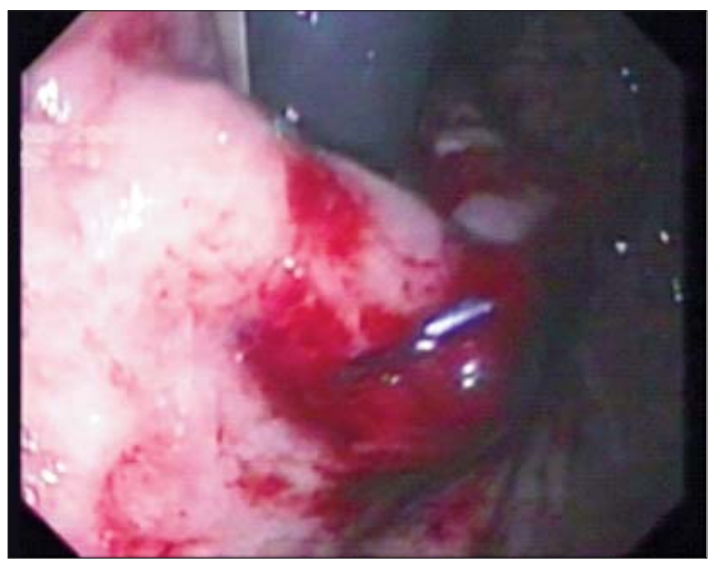

Figure 3. TIF with EsophyX 2, March 2009
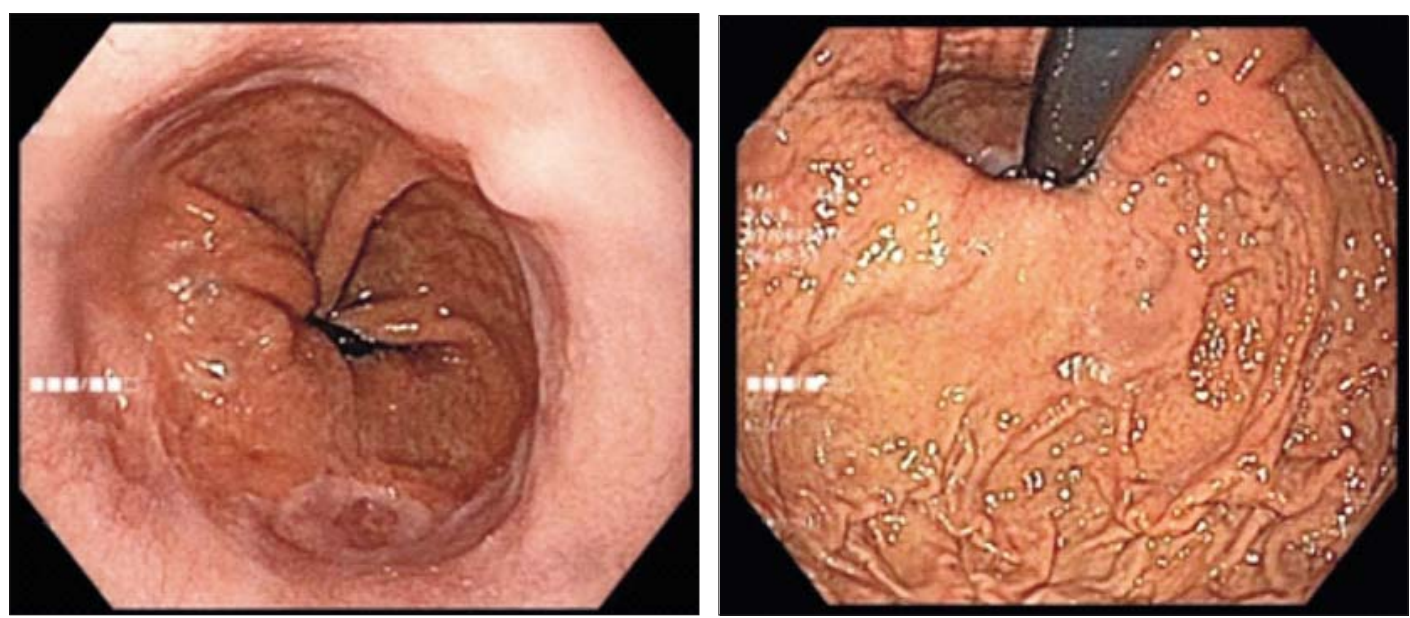

Figure 4. EGD February 2016 


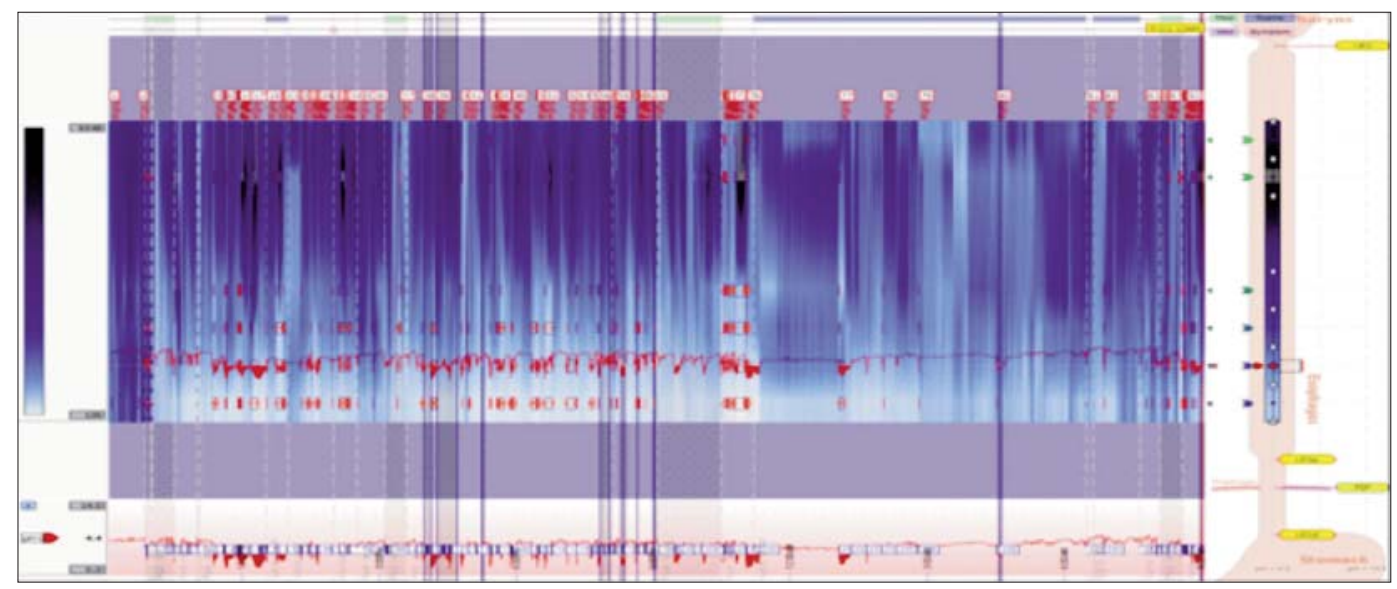

Figure 5. Impedance-pH, February 2016

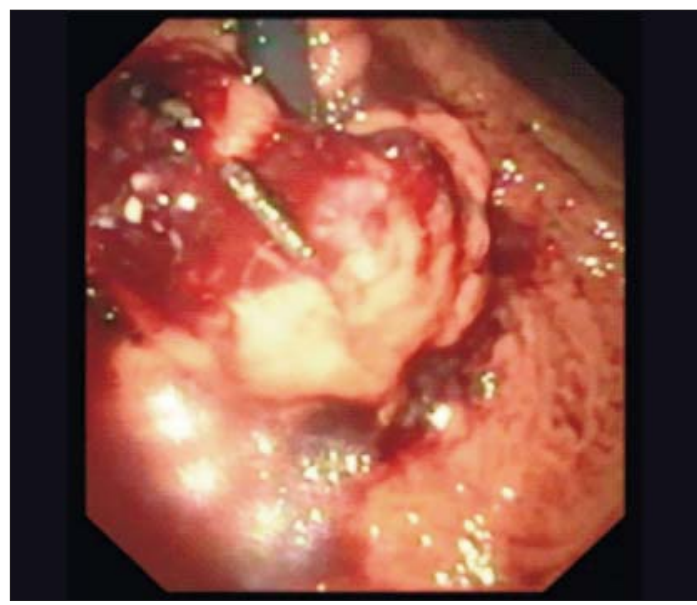

Figure 6. TIF with EsophyX Z, June 2016 a total of 32 fasteners deployed (Fig. 6). The patient is discharged 4 hours later, on routine activity 48 hours post TIF 2.0. The diet is followed for 7 weeks, moderate physical activity for 3 weeks and PPI plus prokinetics therapy for 2 weeks. The EGD is performed at 60 days postop, showing a normal constructed GEJ/fundoplication (Fig. 7).

At 1 year follow up, the $\mathrm{pH}$ impedance test shows a total percent time $\mathrm{pH}<4$ in $2.4 \%$ of time (normal values defined $<5 \%$ ), with a total reflux episodes of 41 (normal values defined as $<73$ ). We noted that the proximal esophagus was abnormally exposed to weekly acid (28 episodes,
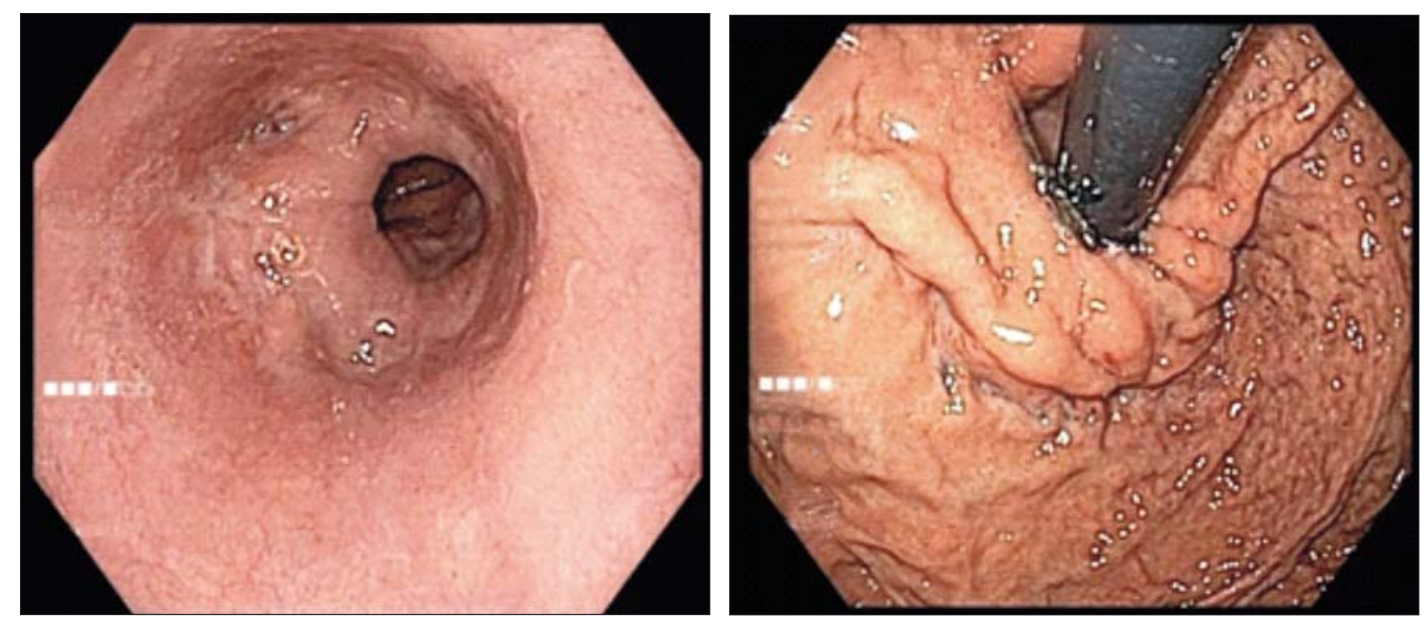

Figure 7. EGD, August 2016 


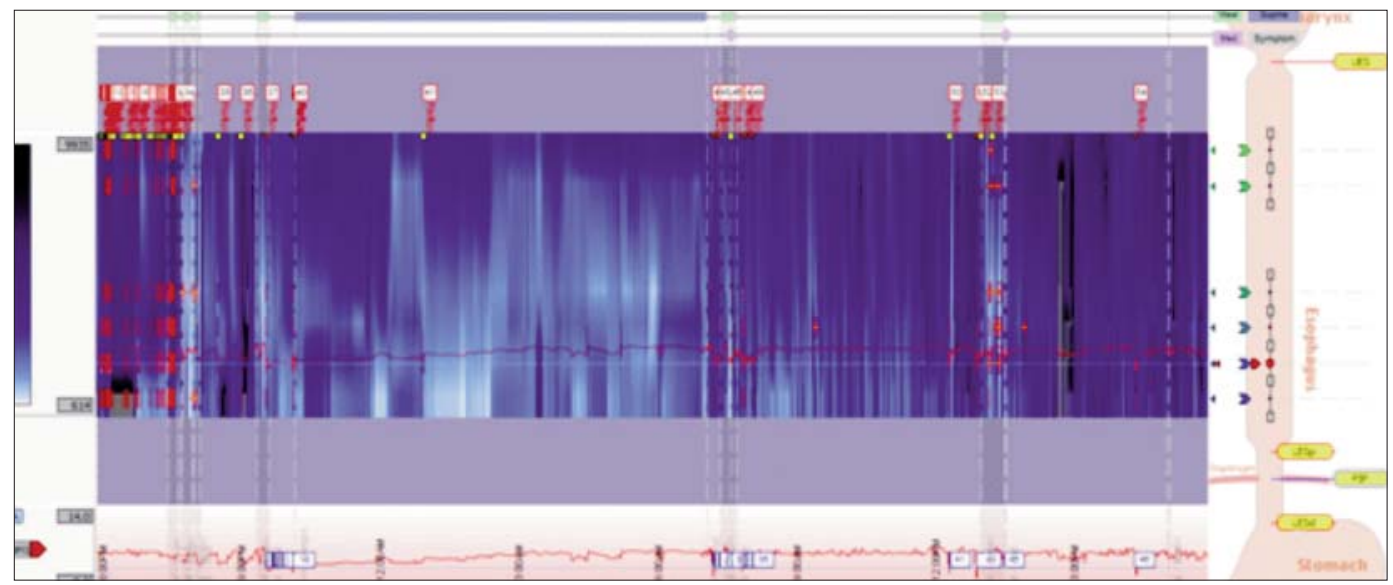

Figure 8. Impedance-pH, July 2017

normal values being defined as <26), which could explain a possible ENT symptoms. The DeMeester score is normal: 8.8 (Fig. 8). The patient is with no symptoms, no treatment, normal diet and intense physical activity.

\section{Discussions}

First Worldwide EndoLuminal Fundoplications (gastro-gastric plications) were performed in Europe 2005, the procedure being cleared by the FDA in 2007. More than 22,000 procedures have been performed as by October 2018, 89 peerreviewed articles published with 1,300 unique patients treated. The quality of life is significantly improved as well as the symptom control, compared to optimized dose on PPI's. The EAE (Esophageal Acid Exposure) is significantly improved, $90 \%$ of patients have demonstrated healing of esophagitis, $71 \%$ of patients being completely off PPI's. The safety profile of the procedure is an exemplary one, with $0.41 \%$ serious Adverse Events (SAE's). We can affirm, the procedure is safer than a colonoscopy, which describes $<1 \%$ SAE's (11).

In our report, the patient himself opted for the endoluminal surgery, which we took in consideration. The medical treatment was not an option, as the patient had anatomical defects, hiatal hernia associated with reflux esophagitis persistent clinical symptoms, atypical symptoms (LPR). Based on this algorithm, where the medical treatment is ineffective, we decided to go for the endoluminal surgery which is less aggressive, and with significant less adverse events compared to Laparoscopic Fundoplications $(12,13)$.

TIF 2.0 is performed with the EsophyX Z device, an over the endoscope device for single use, which, during a single insertion, creates a partial 270 degrees fundoplications, with a minimum of $3 \mathrm{~cm}$ valve length. The gastric fundus is apposed to the distal abdominal esophagus (full thickness plications), secured with 3-0 strength equivalence of polypropylene non resorbable $\mathrm{H}$-shaped fasteners (9).

The TIF 2.0 received in 2017 from SAGES (Society of American Gastrointestinal Surgeons) "strong recommendation", based on a highquality level of clinical evidence +++ for well selected GERD patient population (14). This favorable strong recommendation is based on level I clinical evidence from randomized clinical trials RESPECT, TEMPO and SHAM where TIF 2.0 shows significant superiority compared to optimized PPI therapy a/o SHAM, taking in consideration and evaluating the typical and atypical symptom resolution, healing of esophagitis, significant reduction of the esophageal acid exposure and PPI treatment cessation $(15,16,17)$.

Patient selection is of major importance for optimal patient outcomes. Inclusion crieteria's: objectively confirmed GERD, patients respon- 
sive to PPI's, patients refractory to medication, or partial responders, atypical symptoms (extraesophageal manifestations), moderate esophagitis (Los Angeles Grade A and B), no hiatal hernia or $\mathrm{HH}<2 \mathrm{~cm}$, Hill grade I or II, normal esophageal motility, BMI $<35$, ASA I-III $(12,18)$

Predictive factors of success are: age $>50 \mathrm{Y}$ and GERD-HRQL scores at baseline on PPI's $>15$ (values are from $0^{-}$no symptoms to $50^{-}$ severe maximum symptoms), an average of $20+$ fasteners $(19,20)$. In our case report, the patient was $>50$ years old, received 32 fasteners and was either off PPI's or occasionally on PPI's. A recent Meta-Analysis on 5 RCT's and 13 prospective studies on a total of $963 \mathrm{ELF} / \mathrm{TIF}$ 1.0/TIF 2.0 patients showed significant improvement of typical and atypical symptoms, reduction of total \% time of EAE and significant reduction of reflux episodes. The satisfaction rate at six months was $69,15 \%$, as there were included different iterations of the procedure which today are not performed anymore: ELF and TIF 1.0. The long-time follow-up shows a reduction in efficacy in time although on a side note, one RCT (Witteman) violated inclusion criteria's, including patients with large hiatal hernias and Hill Grade III and IV which represent a contraindication for TIF 2.0 procedures (21).

In our case report, clinical symptoms of GERD after ELF re-appeared at $6 \mathrm{Y}$ after the initial ELF. Also, the $\mathrm{HH}$ was $3 \mathrm{~cm}$ at initial baseline in 2009, or we know today that the maximum $\mathrm{HH}$ for the obtaining the best clinical outcomes and inclusion criteria's are patients with hiatal hernia's no larger than 2 $\mathrm{cm}$. Only 2 fasteners were still identified at the EGD control in 2016. The acid reflux was important with a DeMeester score of 44 . But, there were no typical symptoms. The long-term data on TIF 2.0 has been reported in 2 peer reviewed articles/studies. At 5Y TEMPO Randomized Clinical Trial follow up, 90\% of patients had no more GERD typical or atypical symptoms, the esophagitis healed in $86 \%$, GERD-HLQR mean scores were 5, all esophageal $\mathrm{pH}$ parameters improved, $71 \%$ of patients completely stopped PPI therapy (22). Fourteen patients were followed up long term, at $6 \mathrm{Y}$ post TIF 2.0 with $85,75 \%$ off daily PPI's (20).

In our report, the GERD atypical symptoms re-appeared at more the $6 \mathrm{Y}$ from the initial FEE. This could be explained by a $3 \mathrm{~cm}$ Hiatal Hernia in 2009, with recurrence at $2 \mathrm{~cm}$ in 2015, with new onset esophagitis, important acid reflux with a DeMeester Score at 44, all this without any typical symptoms. Again, we opted for the endoscopic approach, based on the same considerations presented above.

The new EsophyX Z device cleared by the FDA in May 2016 has multiple advantages (compared with the EsophyX2 which is not manufactured anymore by the Company): easier to use, faster procedure time, the fasteners are deployed by automatically activating the trigger, similarly with surgical stapler mechanisms, more efficient, dual fastener deployment, safer for the patients (as stylets are protected), reduced crossing profile (23). Also, the anesthesia is shorter and requires standardized orotracheal intubation, easier to perform than naso-tracheal intubation for ELF and TIF 1.0 procedures with EsophyX 2 device, no more offered nor device manufactured. The time of the procedure is significantly reduced (in our report from 43 minutes to 22 minutes), the procedure having been performed by the same experienced surgeon (A.L.). The patient is today, $2 \mathrm{Y}$ post-procedure symptom-free, EGD is normal, weekly acid reflux with a normal DeMeester score of 8.

TIF 2.0 procedure can be easily re-done, can be performed on failed Nissens (if diaphragmatic defect is less than $2 \mathrm{~cm}$ ) and also, TIF 2.0 does not burn any bridges, as a second TIF 2.0 procedure or a LNF can be easily performed on patients post TIF $(24,25)$. If hiatal hernias are larger than 2 $\mathrm{cm}$, with recent FDA clearance which approved TIF procedure if the hiatal hernia is repaired and reduced below $2 \mathrm{~cm}$ in size, Chang et al., described the concomitant (or hybrid) procedures. The advantage being no post fundoplication new onset symptoms such as dysphagia or gas bloat: laparoscopic approach with or without $\mathrm{HH}$ repair with biologic mesh reinforcement followed by a TIF 2.0 in selected patients (26).

TIF 2.0 being the most successful endo- 
scopic fundoplication, is effective for patients refractory to PPI's. The development of different iterations of devices and techniques was in accordance with obtaining similar effective outcomes proved by the laparoscopic Nissen gold standard procedure. Research are in present conducted which demonstrates long term durability of TIF 2.0 procedure. The longest follow up for the TIF 2.0 procedure was reported at 10 years by Testoni et al (27).

\section{Conclusion}

In conclusion, our case presented has some specifics. The patient is a surgeon with experience in LNF, and one of the authors. We describe the World's first reoperation with "EsophyX Z" with good results at 1Y follow up.

\section{Conflict of Interest}

Adrian Lobontiu, MD is Chief Medical Officer of EndoGastric Solutions.

\section{Authors' Contributions}

$\mathrm{AL}$ performed both surgeries. AEN and $\mathrm{AL}$ equally contributed to the redaction of this manuscript, revised it and submitted for review and publication.

\section{References}

1. El-Serag HB, Sweet S, Winchester CC, Dent J.Update on the epidemiology of gastro-oesophageal reflux disease: a systematic review. Gut. 2014;63(6):871-80.

2. DeMeester TR. Surgical Options for the Treatment of Gastroesophageal Reflux Disease.Gastroenterol Hepatol. 2017; 13(2):128-129.

3. Katz PO, Gerson LB, Vela MF.Guidelines for the diagnosis and management of gastroesophageal reflux disease. Am J Gastroenterol. 2013;108(3):308-28.

4. Neuvonen P, Sand J, Matikainen M, Rantanen T. Does Nissen Fundoplication Provide Lifelong Reflux Control? Symptomatic Outcome After 31-33 Years.World J Surg. 2017;41(8):20462052.

5. Khan F, Maradey-Romero C, Ganocy S, et al.Utilisation of surgical fundoplication for patients with gastro-oesophageal reflux disease in the USA has declined rapidly between 2009 and 2013. Aliment Pharmacol Ther. 2016;43(11):1124-31.

6. Subramanian CR, Triadafilopoulos G. Refractory gastroesophageal reflux disease. Gastroenterol Rep (0xf). 2015;3(1):41-53.

7. Hummel K, Richards W. Endoscopic treatment of gastroesophageal reflux disease. Surg Clin North Am. 2015;95(3):653-67.

8. Nabi Z, Reddy DN.Endoscopic Management of Gastroesophageal Reflux Disease: Revisited. Clin Endosc. 2016;49(5):408-416.

9. http://www.endogastricsolutions.com/technology/esophyx-device/

10. Nicolau AE, Lobonţiu A, Constantinescu G. Endoluminal fundoplication (ELF) with EsophyX2 for gastroesophageal reflux desease (GERD).Chirurgia (Bucur). 2009;104(4):381-7.

11. http://www.endogastricsolutions.com/data/

12. de Bortoli N, Nacci A, Savarino E, Martinucci I, Bellini M, Fattori B, et al. How many cases of laryngopharyngeal reflux suspected by laryngoscopy are gastroesophageal reflux disease-related? World $\mathrm{J}$ Gastroenterol. 2012;18(32):4363-70.

13. Sami Trad K. Transoral incisionless fundoplication: current status. Curr Opin Gastroenterol. 2016;32(4):338-43.

14. http://www.sages.org/publications/guidelines/endoluminal-treatmentsfor-gastroesophageal-reflux-disease-gerd/

15. Hunter JG, Kahrilas PJ, Bell RC, Wilson EB, Trad KS, Dolan JP, et al. Efficacy of transoral fundoplication vs omeprazole for treatment of regurgitation in a randomized controlled trial. Gastroenterology. 2015; 148(2):324-333.e5.

16. Trad KS, Barnes WE, Simoni G, Shughoury AB, Mavrelis PG, Raza M, et al. Transoral incisionless fundoplication effective in eliminating GERD symptoms in partial responders to proton pump inhibitor therapy at 6 months: the TEMPO Randomized Clinical Trial. Surg Innov. 2015; 22(1):26-40.

17. Hțkansson B, Montgomery M, Cadiere GB, Rajan A, Bruley des Varannes S, Lerhun M, et al. Randomised clinical trial: transoral incisionless fundoplication vs. sham intervention to control chronic GERD. Aliment Pharmacol Ther. 2015;42(11-12):1261-70.

18. Saritas Yuksel E, Vaezi MF. Extraesophageal manifestations of gastroesophageal reflux disease: cough, asthma, laryngitis, chest pain. Swiss Med Wkly. 2012;142:w13544.

19. Bell RC, Fox MA, Barnes WE, Mavrelis PG, Sewell RW, Carter BJ, et al. Univariate and multivariate analyses of preoperative factors influencing symptomatic outcomes of transoral fundoplication. Surg Endosc. 2014; 28(10):2949-58

20. Testoni PA, Testoni S, Mazzoleni G, Vailati C, Passaretti S. Long-term efficacy of transoral incisionless fundoplication with Esophyx (Tif 2.0) and factors affecting outcomes in GERD patients followed for up to 6 years: a prospective single-center study. Surg Endosc. 2015;29(9): 2770-80.

21. Huang X, Chen S, Zhao H, Zeng X, Lian J, Tseng Y, et al. Efficacy of transoral incisionless fundoplication (TIF) for the treatment of GERD: a systematic review with meta-analysis. Surg Endosc. 2017;31(3): 1032-1044.

22. Trad KS, Fox MA, Simoni G, Shughoury AB, Mavrelis PG, Raza M, et al.Transoral fundoplication offers durable symptom control for chronic GERD: 3-year report from the TEMPO randomized trial with a crossover arm. Surg Endosc. 2017;31(6):2498-2508.

23. https://www.medgadget.com/2016/05/esophyx-z-gastroesophagealvalve-reconstruction-device-fda-cleared.html

24. Bell RC, Hufford RJ, Fearon J, Freeman KD. Revision of failed traditional fundoplication using EsophyX transoral fundoplication. Surg Endosc. 2013;27(3):761-7.

25. Bell RC, Kurian AA, Freeman KD.Laparoscopic anti-reflux revision surgery after transoral incisionless fundoplication is safe and effective. Surg Endosc. 2015;29(7):1746-52.

26. https://www.sages.org/meetings/annual-meeting/abstracts-archive/ transoral-incisionless-fundoplication-with-laparoscopic-hiatalhernia-repair-reinforced-with-biologic-mesh-outcomes-and-clinicalexperience/

27. Testoni PA, Testoni S. Transoral fundoplication for gastroesophageal reflux disease. Ann Esophagus. 2018;1:7. 